\title{
Erratum to: Ethosuximide ameliorates neurodegenerative disease phenotypes by modulating DAF-16/FOXO target gene expression
}

\author{
Xi Chen ${ }^{1,3}$, Hannah V. McCue1, Shi Quan Wong ${ }^{1}$, Sudhanva S. Kashyap ${ }^{1}$, Brian C. Kraemer², Jeff W. Barclay ${ }^{1}$,
} Robert D. Burgoyne ${ }^{1}$ and Alan Morgan ${ }^{1 *}$

The original version of this article [1] unfortunately contained a mistake. The author list contained a spelling error for the author Hannah V. McCue. The original article has been corrected for this error. The corrected author list is given below:

Xi Chen, Hannah V. McCue, Shi Quan Wong, Sudhanva S. Kashyap, Brian C. Kraemer, Jeff W. Barclay, Robert D. Burgoyne and Alan Morgan

\begin{abstract}
Author details
'Department of Cellular and Molecular Physiology, Institute of Translational Medicine, University of Liverpool, Crown St, Liverpool L69 3BX, UK. ${ }^{2}$ Geriatrics Research Education and Clinical Center, Seattle Veterans Affairs Puget Sound Health Care System and University of Washington Department of Medicine, 1660 South Columbian Way, Seattle 98108 WA, USA. ${ }^{3}$ Present Address: Centre for Neurodegenerative Science, Van Andel Research Institute, 333 Bostwick Avenue NE, Grand Rapids 49503 MI, USA.
\end{abstract}

Received: 6 October 2015 Accepted: 7 October 2015

Published online: 23 October 2015

\section{Reference}

1. Chen X, McCue HV, Wong SQ, Kashyap SS, Kraemer BC, Barclay JW, et al. Ethosuximide ameliorates neurodegenerative disease phenotypes by modulating DAF-16/FOXO target gene expression. Mol Neurodegener. 2015;10:51. doi:10.1186/s13024-015-0046-3.

\footnotetext{
* Correspondence: amorgan@liverpool.ac.uk

'Department of Cellular and Molecular Physiology, Institute of Translational Medicine, University of Liverpool, Crown St, Liverpool L69 3BX, UK

Full list of author information is available at the end of the article

\section{Submit your next manuscript to BioMed Central and take full advantage of:}

- Convenient online submission

- Thorough peer review

- No space constraints or color figure charges

- Immediate publication on acceptance

- Inclusion in PubMed, CAS, Scopus and Google Scholar

- Research which is freely available for redistribution 